\title{
FRA SYGDOMSFORTOLKNING TIL SYGDOMSHÅNDTERING I DET ØSTLIGE UGANDA - OG I ANTROPOLOGIEN
}

\author{
HANNE OVERGAARD MOGENSEN
}

Kvinderne sad på gulvet inden for de røde lerstensvægge, som udgjorde den katolske - og eneste - kirke i landsbyen, en bygning, der også blev brugt som mødelokale i andre sammenhænge. Ved min tilsynekomst rejste de sig straks, vuggede med hofterne, klappede taktfast i hænderne og sang velkomstsange, alt imens småbørnene troligt sov videre på deres rygge. Jeg fortalte med hjælp fra min tolk, at jeg arbejdede sammen med en gruppe mennesker fra Danmark og Uganda, der ønskede at finde ud af noget mere om børnesundheden i Tororo: ${ }^{1}$ „Jeg er hverken læge eller sygeplejerske. Jeg er her bare for at høre, hvad I selv har at sige, og hvad I oplever som jeres største problemer. Hvilke sygdomme findes der her, som sundhedspersonalet ikke får øje på? Hvordan bliver I behandlet, når I tager på sundhedscenteret? Hvorfor er det nogle gange bedre at gå til lokale helbredere, og hvordan behandler I selv sygdomme derhjemme? Hvilken slags medicin kender I? Hvad vil I gerne vide mere om, og hvad synes I, der bør gøres noget ved?" Da min tale sluttede, brød de ud i glædeshyl og taksigelser over, at jeg var kommet, og at jeg ville hjælpe dem med deres problemer.

En kvinde, der havde noteret noget på et papir, rejste sig. „Det er godt,“" sagde hun, ,at du er her for at høre, hvad vi har at sige, og for at tage dig af børnene. Men mødre har også sygdomme, og mødre dør, og nogle gange giver hun sygdommen til sine børn, når hun føder dem, og så dør de.“

„Jeg vil gerne tale med jer om aids, hvis det er det, I vil,“" svarede jeg efter et øjebliks betænkningstid, for aids var blevet nævnt uden navn. „Der er jo ingen medicin, der kan kurere aids, men der er ting, man kan gøre for at mindske chancen for, at barnet smittes ved fødslen." Efter et øjebliks tavshed rejste endnu en kvinde sig og sagde, at de hellere ville tale med mig om børnesygdomme end om aids. Og så var der en, der spurgte, om det var rigtigt forstået, at jeg også gerne ville tale med lokale helbredere, urtespecialister og sandsigere. Min for- 
sikring om, at dette var tilfældet, udløste ny sang og dans og løfter om at bringe disse personer til mit hus.

Formålet med mit et år lange feltarbejde i 1995-96 i landområderne i det østlige Uganda blandt folk, der kalder sig jop'adhola, ${ }^{2}$ var at finde ud af, hvilke diagnoser og forklaringer på børns sygdom omsorgsgiverne (dvs. især børnenes mødre) gjorde brug af, og hvordan beslutninger om behandling af syge børn blev taget. Jeg fulgte dem i deres kamp for børnenes overlevelse og undrede mig mange gange dels over de valg, de traf, dels over, at de undertiden ikke handlede. Eller som jeg nu vil formulere det: min manglende evne til at se, hvori deres handlinger bestod. I denne artikel vil jeg bruge erfaringerne fra dette og senere feltarbejder i samme område til at reflektere over den medicinske antropologis interesse for sygdomsforklaringer og nødvendigheden af også i denne del af antropologien at bevæge sig fra semantik til pragmatik. Det vil i denne forbindelse sige at forstå sygdomsforklaringer ikke kun som en fortolkning af verden og af lidelse, men også som en måde at handle i verden på. Foretager vi ikke denne bevægelse, kommer vi let til fortsat at bidrage til den essentialisering af kultur, der foregår inden for biomedicin og folkesundhed, og de eksisterende forventninger om, at antropologer er eksperter i lokale kulturelle forestillinger, som, når de først er identificeret, kan erstattes med mere korrekt viden og bedre adfærd.

Jeg vil starte med en diskussion af den ,fortolkende tradition“ inden for medicinsk antropologi, hvilken mine første feltarbejder var vokset ud af. Derefter vil jeg gå over til en illustration af, hvordan min analyse med årene har bevæget sig over mod et større fokus på praksis - eller mere præcist: på fortolkning og handling som to sider af samme sag.

\section{Fra biologi til betydning}

Medicinske antropologer har længe forsøgt at argumentere for, at selv om folks reaktioner på sygdom afviger fra det biomedicinske paradigmes vurdering af, hvad der er rationelt, kan disse ikke reduceres til overtro og manglende viden (f.eks. Paul 1955). De er et resultat af et system med en anden logik end den biomedicinske: en kulturel logik, som medicinske antropologer derfor ser det som deres opgave at beskrive (f.eks. Fabrega 1970; Foster 1976).

Men trods dette ihærdige forsøg på at tage et kritisk udgangspunkt har meget medicinsk antropologi alligevel været med til at reproducere det biomedicinske paradigme, netop fordi disse studier tager udgangspunkt i lokale kulturelle forestillinger og sundhedssøgende adfærd (Good 1994:37). De bygger implicit på antagelser fra det biomedicinske paradigme om, at mennesket er et rationelt, værdimaksimerende individ, som forsøger at tilpasse sig sygdom ved at trække 
på en række veldefinerede valgmuligheder (biomedicinske eller andre), motiveret af betydningsbærende elementer, der eksisterer uden for personen selv. Sygdom er i udgangspunktet et objekt, der er adskilt fra menneskelig bevidsthed og kan repræsenteres mere eller mindre korrekt i lokale sygdomsforståelser (op.cit.: 44). At ændre folks „,tro“ (dvs. mindre korrekte forståelser) til viden er og bliver det centrale udgangspunkt for folkesundhedsinitiativer. Antropologer ses fortsat som eksperter i denne „overtro“, i lokale kulturers forestillinger om sygdom og sundhed, som, når de først er blevet identificeret, kan ændres til ,viden“ og hensigtsmæssig adfærd (se Yoder 1997).

Et af de mest konsekvente opgør med det biomedicinske paradigme kommer ifølge Byron Good fra den „,fortolkende“ eller „betydningsorienterede tilgang“ i medicinsk antropologi (the ,interpretive“ eller ,meaning centered tradition“), som særligt Arthur Kleinman repræsenterer, men som Good også selv bidrager til med ideen om semantiske netværk (Good 1977). Kleinman bevæger sig allerede i sine tidlige tekster væk fra et fokus på repræsentation og en forståelse af sygdom som en objektiv og velafgrænset enhed. I stedet ser han sygdom som en „forklaringsmodel“( „explanatory model“), hvilket han definerer som den samling af ideer om en sygdomsepisode og dens behandling, som anvendes af patienten og andre involveret i den terapeutiske proces (Kleinman 1980:105). Kultur, siger han, er ikke en måde at repræsentere sygdom på, men et grundlæggende element i den menneskelige væren. Kulturen og dens symboler er broen mellem den menneskelige krop og det intersubjektive (Kleinman 1973, 1980). Komplekse menneskelige fænomener bliver måske nok formet som (og reduceret til) sygdomme og gjort til objekt for biomedicinen (Kleinman \& Kleinman 1991). Men sygdom, siger Kleinman inspireret af Geertz og hans idé om mennesket som ophængt i et væv af betydning, det selv har spundet (Geertz 1973:5), kan grundlæggende kun forstås, hvis vi går gennem menneskets fortolkning af dets lidelse.

Denne udvikling i den medicinske antropologi foregik parallelt med den generelle antropologis bevægelse fra en modernistisk disciplin til en hermeneutisk inspireret disciplin. Inspireret af biologien udviklede der sig i mellemkrigsårene i det 20. århundrede funktionalistiske og strukturfunktionalistiske teorier om samfundet, der havde naturvidenskaben og positivismen som forbillede (Hastrup 2005:135). Da inspirationen fra sprogvidenskaben holdt sit indtog, var det i første omgang også med en positivistisk forventning om, at sprog og dermed også kulturer (eller medicinske systemer) eksisterede som objektive fænomener uafhængigt af det talte ord eller folks handlinger. Inspireret af Ardener foreslår Hastrup dog, at den lingvistiske drejning og ikke mindst inspirationen fra semantikken resulterede i den britiske antropologis spring fra ,funktion“til „,betydning“, hvorved grunden blev lagt til den hermeneutiske drejning, som karakteriserede 
antropologien 1980'erne (op.cit.:135-6). Denne var i USA blevet bebudet af Clifford Geertz allerede i 1970'erne, og han var som nævnt den centrale inspirationskilde for Arthur Kleinman og den medicinske antropologis ,fortolkende“ traditions opgør med sygdom som objektiv enhed, hvilket jeg nu vil vende tilbage til gennem en diskussion af egen empiri.

Før mit feltarbejde i Uganda havde jeg i 1993 lavet et feltarbejde i Zambia om lokale fortolkninger af aids (Mogensen 1995, 1996, 1997; Gausset \& Mogensen 1996). „Aids er nogenlunde det samme som kahungo,“ svarede folk, når de blev spurgt, hvad de kendte til „denne nye sygdom“, som aids stadig var i 1993. Kahungo var kendt som sygdommen, man fik, når man var i fysisk kontakt med en kvinde, der havde aborteret, før denne kvinde havde været igennem det renselsesritual, som var påkrævet efter en abort. Det viste sig snart, at kahungo var del af et større kompleks af sygdomme, der mentes at være forårsaget af upassende kontakt mellem to personer, blanding af blod, der ikke bør blandes, og af liv og død. Når samtalen faldt på den ene af disse sygdomme, udviklede den sig ofte til at omhandle en anden. De flød sammen og var bundet sammen af, at alle var karakteriseret ved, at nogen eller noget var citasalale, dvs. ,uklart“, „urent", „ikke var, som det burde være“: to i én, liv og død i én og samme person, blanding af blod og kropsvæsker fra folk, der ikke hørte sammen, osv. Der var med andre - eller mere præcist med Mary Douglas' - ord tale om, at noget var „out of order“ (Douglas 1966). Et sådant kompleks af sygdomme forårsaget af uorden relateret til sex, liv og død genfindes over store dele af det sydlige Afrika, om end sygdommene kaldes og konstrueres forskelligt fra sted til sted (se Gausset \& Mogensen 1996 for yderligere diskussion af dette).

I 1993 var forståelsen af kahungo tydeligvis under forandring, påvirket af folks stigende kendskab til og erfaringer med aids. Kahungo, sagde de, var blevet værre, hyppigere og sværere at gøre noget ved på grund af aids. Ydermere blev det efterhånden tydeligt, at kahungo tidligere havde været associeret med kønssygdomme og tuberkulose. Kahungo så altså ud til at være del af et sygdomskompleks, gennem hvilket erfaringer med nye og skræmmende sygdomme kunne fortolkes, særligt når der var tale om nye sygdomme, der ledte tankerne hen på den uorden, der forårsages af modernisering og urbanisering (Mogensen 1996). De mange fortællinger om kahungo og aids afveg alle en smule fra hinanden. De var baseret på folks egne erfaringer, om end de også bar præg af en fælles fortælling om uorden. Aids var ifølge de zambianske tongaer i starten af 1990'erne noget, der bare skete, fordi verden forandrede sig på uhensigtsmæssige måder. Ikke fordi nogen havde sendt sygdommen (Mogensen 1995, 1997).

I forsøget på at indfange denne foranderlige fortolkningsproces vendte jeg mig mod narrativbegrebet, som i slutningen af 1980'erne og 1990'erne kom til at 
spille en central rolle i det, som Hastrup (2005:136) henviser til som den litterære vending $\mathrm{i}$ antropologien, der erstattede den lingvistiske vending. Med udgangspunkt $i$ en hermeneutisk forståelse af, at vores adgang til verden nødvendigvis går gennem de kulturelle former, gennem hvilke mennesket fortolker verden, søgte antropologien i 1980'erne efter måder at indfange individuelle erfaringer på såvel som kollektive rammer for fortolkning, forandring såvel som kontinuitet (se bl.a. Bruner 1986a og b) og fandt bl.a. inspiration i litteraturvidenskabens diskussion af narrativer, ikke mindst Paul Ricoeur (1991). Narrativer kom også til at spille en central rolle i den medicinske antropologis forsøg på at indfange det komplekse forhold mellem kropslig erfaring og de kulturelle former, den fortolkes igennem (Good 1994:135-65).

Ved planlægningen af feltarbejde i Uganda var det de zambianske tongaers brug af et narrativ om uorden (frem for f.eks. et narrativ om hekseri og anklage), der inspirerede mig til at kigge nærmere på, hvordan folk i konkrete sygdomsepisoder gør brug af de forskellige narrative strukturer, der er tilgængelige for dem. Jeg måtte derfor starte med at kortlægge, hvad der eksisterede af lokale diagnoser blandt jop'adholaerne i det østlige Uganda, eller som jeg nu tænkte det: kortlægge de narrative strukturer, der blev brugt i fortolkningen af børns sygdom.

\section{Jop'adholaernes fortolkning af sygdom}

Det indledende spørgsmål i mange af mine første interviews i Uganda var: „Hvad er de mest almindelige børnesygdomme her i området?" I det følgende vil jeg skitsere nogle af de diagnoser, jeg fik beskrevet som svar på dette spørgsmål. Senere vil jeg gå over til en illustration af, hvordan de blev anvendt i konkrete sygdomsepisoder, og hvordan min deltagelse i disse kombineret med en brug af narrativer som analytisk begreb var med til at nuancere min forståelse af, hvad der er på spil, når man diagnosticerer en syg person.

Jeg fik altid at vide, at de mest almindelige børnesygdomme var koyo og musujja, eller snarere musujja var den mest almindelige og koyo den mest alvorlige. Symptomerne kunne minde om hinanden (diverse almindeligt forekommende symptomer som snue, hoste, feber, diarré m.m.), men koyo var yderligere karakteriseret ved, at der af og til kom udslæt. Jeg fik desuden at vide, at alle får koyo flere gange i deres liv. Det er uundgåeligt, alvorligt og den mest almindelige årsag til dødsfald blandt børn. Koyo blev af alle i området, om de kunne engelsk eller ej, oversat til mæslinger, selv om mæslinger, som det defineres af biomedicinere, efterhånden var sjældent forekommende på grund af den høje vaccinationsdækning i området. Tilsvarende blev musujja uden tøven oversat til malaria. Både koyo og musujja kunne behandles hjemme med urter eller piller 
(f.eks. diverse smertestillende tabletter eller klorokin mod malaria) købt hos lokale medicinforhandlere med mere eller mindre officiel status som apotek. Men især koyo tog man på sundhedscenteret med, hvis penge og tiden tillod det.

Juok kunne hospitalet derimod ikke gøre noget ved. Denne ofte anvendte betegnelse kunne bruges om konkrete sygdomsepisoder eller dødsfald, men blev især benyttet i tilfælde af længerevarende eller tilbagevendende sygdom, ikke mindst hos børn. Længerevarende sygdom stiller større krav til placering af årsag, end isolerede episoder af f.eks. koyo eller musujja gør, og her har juok noget at bidrage med, hvorimod juok som diagnose intet siger om symptomer. Juok (juogi i flertal) findes som begreb blandt mange nilotiske folk i det østlige Afrika, ${ }^{3}$ og selv om der er forskel på, hvordan det defineres og bruges, er der også mange lighedspunkter (se Mogensen 2002). Blandt jop'adholaerne henviser flertalsformen (juogi) til klanens forfædre, en kollektiv gruppe af afdøde, men i høj grad tilstedeværende slægtninge, der på godt og ondt griber ind $\mathrm{i}$ de levendes liv. Juok (entalsform) bruges til at henvise til diverse forunderligheder som f.eks. tvillinger eller en person, der er exceptionelt god til at løbe, studere eller andet. Det kan også bruges om det at sende noget ondt mod en anden, dvs. at det også dækker over de fænomener, der i antropologisk litteratur oversættes til hekseri (,witchcraft") og trolddom (,,sorcery“). Der henvises hos jop'adholaerne også til børnesygdomme, der minder om de ,uordenssygdomme“, jeg beskrev fra Zambia. Et barn får chilo, dvs. bliver tyndt, svagt og skrantende, hvis dets far er dets mor utro, mens hun stadig ammer. Theri med tilsvarende symptomer opstår, når en kvinde bliver gravid, mens hun stadig ammer. Kidimbia henviser til et skrantende barn, der tilmed har udspilet mave og tyndt lyst hår (symptomer, der leder tankerne hen mod fejlernæring), og skyldes brud på det sæt af regler (tabu), som enhver klan er underlagt.

Flere andre diagnoser kunne nævnes, men ovenstående eksempler skulle være tilstrækkelige til at illustrere, at der også blandt jop'adholaerne findes en række diagnoser, der kan henvises til som narrative strukturer, fordi de på forskellig vis tillægger lidelse betydning ved at kæde sygdom sammen med folks erfaringer med livet og døden, med tiden før og nu og med ens nære sociale relationer såvel som det bredere samfund. Ud over varierende former for behandling af disse sygdomme har jop'adholaerne også adgang til sundhedscentre og hospitaler inden for gåafstand af langt de fleste bosteder. Disse anvendes hyppigt og tilbyder - med varierende effektivitet og kvalitet - biomedicinsk behandling af diverse almindelige symptomer og sygdomme som malaria, diarré, luftvejsinfektioner m.m. Hvilken rolle spiller de ovenfor beskrevne diagnoser eller narrative strukturer da i mødet med sundhedscentrene og sundhedsarbejderne? Dette vil jeg nu kigge på ved at tage udgangspunkt i et tværfagligt studie fra 1996 af „Quality of Care“ 
(kvaliteten af behandling/omsorg) i seks sundhedscentre i det østlige Uganda, heraf to, der lå i det område, hvor jeg på det tidspunkt var på feltarbejde. ${ }^{4}$

\section{Fraværet af fortolkning?}

Det var Arthur Kleinmans idé om sygdom som indlejret i kulturelle fortolkninger og som noget, man kan nærme sig gennem forklaringsmodeller, der lå bag det antropologiske bidrag til ovennævnte studie. Jeg deltog i den del af undersøgelsen, der bestod i semistrukturerede interviews med folk, når de kom ud fra konsultationen, som vi kaldte „exit interview“. Folk blev bl.a. spurgt om, hvad de mente, der havde været galt med dem (eller som det oftest var tilfældet, med det syge barn, de var kommet med), inden de kom til sundhedscenteret, hvad de havde forklaret til sundhedsarbejderen, hvad de spurgte ham/hende om, hvad han/hun spurgte dem om, og hvilken sygdom han/hun havde sagt, det handlede om.

Ved gennemlæsning af de 160 semistrukturerede interviews slog det mig, at der var en bemærkelsesværdig mangel på forventning om, at man som patient ville få forklaringer og afklaringer på sundhedscenteret. Man kom for at få behandling, og ens tilfredshed med besøget afhang af, om man kom derfra med medicin uden at have betalt for meget for den. Når folk blev spurgt, hvad de troede, der var galt med dem, inden de ankom, svarede de f.eks., at de ikke vidste, hvilken sygdom de havde, men at de havde fortalt sundhedsarbejderen, hvori deres symptomer bestod, og at sundhedsarbejderen havde bekræftet, at der var tale om f.eks. feber og smerter i brystet, og skrevet dette ned på et stykke papir, som moderen havde brugt til at få udleveret medicin til drengen. Stort set alle svarede, at de ikke havde stillet nogen spørgsmål, for sundhedsarbejderen havde allerede forstået, hvad deres symptomer var, og udskrevet medicin til dem på recepten. Enkelte sagde, de havde stillet nogle spørgsmål om, hvad de nu skulle gøre, hvor de skulle gå hen efter indsprøjtning eller medicin, hvordan de skulle tage den osv. Men endnu mere bemærkelsesværdigt var den tilsyneladende manglende interesse for at få sundhedsarbejderen til at stille en diagnose, og om denne stemte overens med det, man selv havde forestillet sig, inden man kom. Følgende er nogle eksempler på, hvad folk svarede, når vi spurgte til dette:

Jeg blev ikke fortalt noget om barnets sygdom. Han spurgte mig, hvad problemet var, og jeg beskrev barnets symptomer.

Han satte ikke noget navn på sygdommen, men det er heller ikke meningen, han skal det. Han skal spørge, hvad barnet lider af, og så skal jeg fortælle ham, hvad problemet er. Sundhedsarbejdere giver ikke forklaringer. De skriver ned, hvilken medicin man skal tage. 
Hvad forventer du, at sundhedsarbejderen skulle fortælle mig? Det er mig, der ved, hvad jeg lider af. Det var mig, der fortalte ham, hvad der var galt, og det var ham, der gav mig medicin.“

Disse svar giver stof til eftertanke og grund til et kritisk blik på vores måde at spørge på. Implicit i vores spørgsmål var en forventning om, at folk ville ankomme til sundhedscenteret med én forklaringsmodel (f.eks. baseret på en af de ovenfor nævnte diagnoser) og ville få denne revideret i mødet med sundhedsarbejderens anderledes forklaringsmodel. Antropologer har ofte pointeret, at det biomedicinske system bygger på en formodning om, at sundhedsarbejderne kan afkode folks upålidelige forklaringsmodeller og bag patientens oplevelse af lidelse identificere en autentisk sygdom: en biologisk patologi (Kleinman 1995:32). I dette studie ser det dog ud til, at det hverken var sundhedsarbejderne eller patienterne, der forventede dette, men forskerne. Vi forventede en bevægelse fra patienterfaringer til biomedicinsk diagnose, men patienterne forsøgte end ikke at give udtryk for deres fortolkning gennem brug af de ovenfor beskrevne diagnoser, og de så sig selv - og ikke sundhedsarbejderne - som dem, der afgjorde, hvad deres problem var. De beskrev de symptomer, der havde generet dem inden for de sidste dage, eventuelt op til en uge, og de forventede ikke, at sundhedsarbejderen ville have noget nyt eller overraskende at sige til dette, blot at han/hun ville udskrive noget medicin til dem.

På trods af den „fortolkende traditions“ forsøg på at tage et markant andet epistemologisk udgangspunkt, dvs. i sygdom som kulturelt fænomen frem for kulturelle repræsentationer af sygdom (jf. Good 1994:52-6), sker der ofte det, at man kommer til at bekræfte elementer af det biomedicinske paradigme, selv om man tager udgangspunkt i forklaringsmodeller, semantiske netværk eller narrative strukturer. I dette eksempel bekræftede vores spørgsmål implicitte antagelser om, at individer gør brug af fortolkningsmuligheder, der eksisterer uafhængigt af personen selv, hvilket giver dem en række valgmuligheder, de kan trække på, i deres forsøg på at tilpasse sig den situation, sygdommen har skabt. Desuden forventede vi, at disse fortolkninger ville blive revideret i mødet med en mere autoritær videnstradition (jf. Good 1994:37-47). Men ikke nok med, at hverken sundhedsarbejderne eller informanterne så ud til at have nogen forventning om at skulle udveksle og revidere forklaringsmodeller. Disse forklaringsmodeller spillede umiddelbart slet ingen rolle i konsultationen. Hvad var der så på spil?

Som Hastrup skriver, var den hermeneutiske inspiration og den litterære vending i antropologien på mange måde en fortsættelse af den lingvistiske vending, med det forbehold, at den litterære vending indebar et epistemologisk angreb på positivismen og et fokus på den sociale konstruktion af virkeligheden (Hastrup 2005:136), om end, som hun tilføjer, det sociale aspekt af denne konstruktion 
ofte ender med at blive negligeret. I det følgende vil jeg forsøge at demonstrere, at det netop også ofte er det, der sker i studier af fortolkning af sygdom, og at første skridt mod en forståelse af praksis går gennem en inddragelse af den sociale kontekst.

En af respondenterne i exitinterviewene var en 19-årig kvinde med en datter på syv måneder, der var syg. Kvinden svarede som andre, at hun havde besluttet at tage til sundhedscenteret på grund af en række symptomer, datteren havde: diarré, hoste og feber. Sundhedsarbejderen havde ikke spurgt om noget, og han havde ikke forklaret noget. Hun havde fortalt ham, hvilke symptomer datteren havde, og at de var startet dagen forinden bortset fra hosten, der startede for fire dage siden. Sundhedsarbejderen havde følt på den lille piges mave, taget hendes temperatur, bedt moderen om at give pigen frisk komælk og at komme tilbage med hende dagen efter. Moderen sagde, hun havde forstået det hele og ikke havde haft noget at spørge om.

Efter interviewet begyndte hun at fortælle mere frit: „Min datter blev født i juli. Efter fire måneder fik jeg menstruation igen i tre måneder, men nu er det holdt op.“ „Hun prøver at fortælle os, at hun tror, hun er gravid, og at hun er bange for, at hendes barn har theri,“ sagde min ugandiske kollega til mig på engelsk og henviste dermed til frygten for, at et barn, der stadig får bryst, bliver sygt, hvis moderen bliver gravid igen. Kvinden, der forstod en smule engelsk, nikkede bekræftende og fortalte videre om sine bekymringer ved tanken om, at hun måtte holde op med at amme, at der ikke var nok at spise derhjemme, og da slet ikke komælk, som hun kunne give sin datter i stedet for brystmælk. Hendes mand og svigerforældre var tilfredse med, at hun var gravid igen, men bekymrede sig slet ikke nok om, hvorvidt hun og datteren fik nok at spise.

Akoth, som kvinden hed, havde tydeligvis bekymringer, der gik ud over det, hun havde fået plads til at udtrykke i konsultationen, men hun udtrykte ikke forventninger om, at det var det rette sted at bringe dem på banen. Hvorfor bragte den unge kvinde så theri op i den efterfølgende samtale med os? Var der alligevel et behov for forklaring, noget uforløst erfaring, hun ikke havde fået plads til i løbet af konsultationen? Er hun, som Kleinman og Kleinman (1991) ville formulere det, et eksempel på, at komplekse menneskelige fænomener i biomedicinske behandlingsinstitutioner reduceres til sygdom og gøres til objekt for klorokinindsprøjtninger og tabletter? Dette vil måske nok være en måde at forklare det på, men en måde, der samtidig overser et centralt aspekt af, hvad der rent faktisk foregår mellem sundhedsarbejderen og patienten - og hvad der foregår uden for sundhedscenteret, når de lokale diagnoser tages i brug. Det ville være at overse folks forsøg på at handle i en bestemt social kontekst, samtidig med at de forsøger at fortolke og forstå. 
Udfordringen er, som Byron Good (1994:55) og Arthur Kleinman også selv siger i løbet af 1990'erne, ikke kun at undersøge forholdet mellem erfaring og de kulturelle former, hvorigennem de fortolkes, men også hvordan denne erfaring er indlejret i det, som Kleinman (1995) kalder lokale moralske verdener, dvs. sociale verdener, hvor noget er på spil, som aktørerne kæmper for at opnå eller undgå at miste. Med andre ord er folk hele tiden i gang med at respondere på andre aktører i den sociale kontekst, de lever i, og deres fortolkning af verden er altid på én og samme tid et forsøg på at handle i verden og kæmpe for det, der betyder noget for dem. På sundhedscenteret forsøger folk også at række ud i verden, men her er der tale om andre sociale og temporale kontekster end blandt familien og hjemme i landsbyen og derfor andre måder at gøre det på end ved at bruge de ovenfor beskrevne diagnoser.

Hastrup forudser i sin artikel om antropologiens centrale vendinger i det sidste århundrede, at faget nu er i gang med en bevægelse over mod pragmatismen og en forståelse for, at samfundets kompleksitet opstår gennem praksis, og samfundet kun eksisterer i kraft af folks handlinger (Hastrup 2005:140). ${ }^{5}$ I det følgende vil jeg vise, hvordan jeg i min egen bevægelse over mod praksis fortsatte med at gå gennem narrativer og i særdeleshed var inspireret af Cheryl Mattingly og hendes diskussion af narrativer som handlede, før de er fortalt (Mattingly 1994, 1998). Jeg vil nu vende tilbage til Akoth og andre eksempler fra Uganda og bruge den resterende del af denne artikel til at vise, at sygdomsfortolkning i sig selv er handling snarere end fortolkning. Det, der i starten af mit feltarbejde til tider lignede fravær af handlinger fra mødrenes side, drejede sig snarere om min manglende evne til at se de subtile måder, hvorpå de handlede gennem fortolkning af deres børns symptomer.

\section{Fra betydning til praksis: Hvem?}

Ved et opfølgende besøg hos den interviewede kvinde, Akoth, fik vi at vide, at hendes syv måneder gamle datter, hvis symptomer hun på sundhedscenteret havde beskrevet som havende haft en varighed af henholdsvis en og fire dage, $i$ realiteten havde skrantet i flere måneder. Moderen følte ikke, hun havde mælk nok til hende, og hun følte sig magtesløs over for, hvordan hun skulle skaffe anden mad til hende, ikke mindst nu i lyset af den nye graviditet, der betød, at hun tilmed blev nødt til at holde op med at amme. Hendes mand og svigerforældre tog ikke problemet alvorligt. De bifaldt den nye graviditet, men der var ikke tegn på, at der af den årsag ville falde mere støtte af til hende.

Castle (1994) beskriver fra sit feltarbejde i Mali, hvordan diagnoser kendt for at lede mod en sikker død (kaldet foondu og heendu) ikke kan stilles af hvem som 
helst. Faktisk stilles de oftest af ældre kvindelige familiemedlemmer, normalt moderens svigermor. Samtidig påpeger Castle, at det er diagnoser, der spiller den vigtige rolle at fratage moderen ansvaret for barnets død. De er en konstatering af, at dette dødsfald var uundgåeligt, og at moderen ikke ved yderligere handlinger kunne have forhindret det. Castles diskussion af disse to sociale aspekter af diagnosticering - hvem der kan stille en diagnose, og hvad denne diagnose kommunikerer om ansvar - har været til stor inspiration for mig i min analyse af jop'adholaernes diagnosticering af deres børn.

Theri er en diagnose, som en mor selv kan spille en aktiv rolle $\mathrm{i}$ at nå frem til, da kun hun kender detaljerne om den nye graviditet, om end det forventes, at ældre kvinder går ind og bekræfter vurderingen. Ved at pege på theri gjorde Akoth opmærksom på, at datterens skrantende helbred skyldtes, at hun selv var på vej til at bidrage med endnu et barn til familien, og at dette krævede anerkendelse og støtte i form af mælk (og anden mad) nu, hvor hun ikke længere kunne amme. Det var en diagnose, hun selv kunne stille, og gennem hvilken hun kunne kommunikere nogle forventninger til andres ansvar over for hende og hendes børn.

En anden kvinde, Awori, havde mistet to børn på henholdsvis fem og seks måneder og ventede nu sit tredje. Awori mente (og havde fået bekræftet hos en sandsiger), at juogi (klanens forfædreånder) var på spil, fordi familien havde forsømt afholdelsen af en større ceremoni. Men hendes svigerfar, der var ansvarlig for at afholde denne ceremoni, ville ikke anerkende hendes udlægning. Han insisterede på, at svigerdatterens børn var døde af „hospitalssygdomme“, fordi hun var hurtig til at reagere og tage på sundhedscenteret, når de var syge. Awori var ikke velanset af sine svigerforældre af flere forskellige årsager. De sagde bl.a., at hun på grund af sine syv års skolegang var næsvis og bedrevidende, at hun var doven, og at hun tilmed ikke kunne holde liv i sine børn. Awori havde været gift med eller rettere boet sammen med sin mand i snart tre år, men hans forældre havde endnu ikke betalt brudepris for hende. Uden denne var hun ikke rigtig gift og kunne i princippet blive smidt ud når som helst. Det er normalt, at det kan tage flere år at få det hele betalt, men der var ingen tegn på, at svigerforældrene ville tage initiativ til overhovedet at komme i gang, og Awori bemærkede denne manglende værdsættelse af hende som svigerdatter. Awori understregede, at hun havde gjort alt, hvad hun kunne, og alt, hvad der i hendes øjne forventedes af en veloplyst og skolet mor, som hun anså sig selv for at være. Men så længe svigerfaderen ikke ville påtage sig sin del af ansvaret, ville også hendes fremtidige børn være i stor fare, sagde hun. Uden svigerfaderens anerkendelse af hende som svigerdatter havde hun også haft svært ved at få andre i familien til at hjælpe med betaling af gebyrer og medicin på sundhedscenteret eller til f.eks. at få adgang til frisk mælk fra familiens ko. 
Svigerfaderen lagde på sin side ikke skjul på, at en betaling af brudeprisen ville være en anerkendelse af en kvinde, som han ikke var sikker på, han ønskede som svigerdatter. Hans åbenlyse benægtelse af juogis rolle i børnenes død var ydermere en benægtelse af hans del af ansvaret. Ved at sende hende på sundhedscenteret kommunikerede svigerfaderen en uvilje mod at påtage sig det endelig ansvar, for som kvinderne af og til udtrykker det: „Hospitalet er for dem, der ingen har til at hjælpe sig." Biomedicinsk behandling kan være effektiv og tilgængelig (om end der er finansielle udgifter forbundet med den) og uden behov for komplicerede forhandlinger med familien. Men den kan samtidig også opleves som det eneste, man har at ty til, når man ingen støtte har fra familien (se Mogensen 1999 for yderligere analyse af denne case).

De ovenfor beskrevne diagnoser, som jeg identificerede hos jop'adholaerne $\mathrm{i}$ Uganda, indeholder alle implicitte normer for, hvem der kan diagnosticere dem, og hvem der kan og skal handle over for sygdommen. Koyo og musujja kan diagnosticeres af mødrene selv og kræver normalt tabletter eller et besøg på sundhedscenteret, som moderen selv kan tage initiativ til, og som er økonomisk muligt for mange kvinder meget af tiden, om end de til tider må søge hjælp fra manden eller andre slægtninge for at få råd til medicin, indlæggelse eller blot gentagne og langvarige behandlinger. Når juok kommer på tale, kan det som sagt være af neutrale, ,uheldige“ årsager, som ingen holdes ansvarlig for, men ansvaret for at handle ligger hos barnets faders slægtninge. Juok/juogi kan også have mindre neutrale årsager. En slægtning kan f.eks. have forbrudt sig mod regler og normer eller decideret ønsket at sende ondt mod en anden. Under alle omstændigheder er det barnets faders klan, dvs. i praksis dets far eller farfar, der bør reagere og igangsætte nødvendige handlinger. Ved længere tids sygdom begynder mødre ofte at overveje, om deres barns skrantende helbred kan tilskrives en af sygdommene forårsaget af ,uorden“, men den endelige diagnose og igangsættelse af behandling afhænger af ældre kvinder i den nærmeste eller lidt fjernere familie.

Inspireret af Castles arbejde i Mali (1994) vil jeg påpege, at ansvar for diagnosticering og for at (be)handle er et ofte overset aspekt af, hvordan diagnoser defineres. Normalt defineres diagnoser først og fremmest ved årsager, symptomer og behandling, men i den løbende fortolkning af et barns symptomer og generelle velvære vil spørgsmål om ansvar være en altid nærværende faktor. Dermed ikke sagt at mødre som Akoth og Awori frit vælger en diagnose ud fra, hvis opmærksomhed de gerne vil påkalde sig, men som Hastrup (2004) siger, er vores handlinger altid rettet mod nogen eller noget. Grundlæggende handler vi for at respondere på det, vi møder inden for den moralske horisont og sociale kontekst, vi befinder os i. 
Diagnoser kan ses som narrativer. Når mødre fortolker deres erfaringer med børns sygdom, gør de det inden for en række narrative strukturer, der på forskellig vis forbinder sygdom og lidelse til livets kompleksitet, ikke gennem kausalsammenhænge, men gennem en narrativ logik, et „plot“, eller som vi ville oversætte det til på dansk: logikken iboende fortællingens handling. Når Paul Ricoeur taler om handling (plot), henviser han ikke til en færdig struktur i narrativet/fortællingen, men til et engagement i det, der allerede er blevet fortalt i forhold til forestillingen om, hvad der nu måtte komme. Det er i læsningen af historien, at handlingen skabes - i interaktionen mellem teksten og læseren (Ricoeur 1991). At give en fortælling handling betyder, at man i øjeblikket, i nuet, bruger det allerede skete (fortiden) og kaster det ind i fremtiden i en formodning om, hvad der nu måtte ske. Mattingly $(1994,1998)$ tager denne indsigt fra fortællingens verden med ind i en forståelse af praksis og konstaterer, at narrativer er levet, før de er fortalt. Når vi handler, er vi også hele tiden i gang med at ,skabe handling“ ("to emplot" på engelsk). I nuet handler vi ved at trække på noget allerede erfaret (fortiden), og det gør vi på en måde, der er påvirket af vores forventning om, hvor vi er på vej hen (hvordan fremtiden ser ud). Livet er ikke en fortælling. Det har ikke en handling, som en bog eller en afrundet fortælling har det, da vi ikke kender slutningen. Men som Ricoeur, der bruger „handling“ om læserens engagement i teksten, henviser Mattingly til ,aktørens engagement i livet". Vi følger med i, hvad der er sket, håber, formoder og gør ting for at nå frem til visse resultater og ikke mindst for at få andre til at bevæge sig i samme retning og hjælpe os på vej. På vores vej frem må vi som Akoth og Awori hele tiden forholde os til andre aktører og deres forsøg på at nå andre (eller samme) mål. Vi må respondere - eller „svare“ - på deres handlinger på måder, der tilsvarende skaber hensigtsmæssige gensvar - eller ,ansvar“ - fra dem.

\section{Fra betydning til praksis: Hvornår?}

Narrativer forbinder begivenheder over tid. I nuet bruger man det allerede skete, fortiden, og kaster dette ind i fremtiden i en formodning om, hvad der kommer til at ske (Bruner 1986). Netop tidsperspektivet er også afgørende i forbindelse med fortolkning af sygdom. For at illustrere dette vil jeg vende mig mod den debat, der i slutningen af 1980'erne og i 1990'erne voksede ud af Scheper-Hughes' arbejde om mødres omsorg for børn i det nordøstlige Brasilien.

Scheper-Hughes $(1985,1992)$ argumenterer for, at der blandt mødre i det nordøstlige Brasilien er en udbredt fatalisme, der bl.a. kommer til udtryk i diagnosen doenca de crianca, der henviser til børn, som man ikke forventer kan overleve, og at fattigdom tvinger mødre til at udvælge de børn, der har størst chance for at 
overleve, og at forsømme andre. Nations og Rebhun (1988) argumenterer for, at Scheper-Hughes i sin analyse overser tidsperspektivet, og de viser, at fatalistiske forklaringer ofte er ,post factum“-forklaringer, der gives efter et barns dødsfald og gør sorgen lettere at bære. Castle (1994) beskriver fra sit feltarbejde i Mali, hvordan de førnævnte diagnoser, der er kendt for at lede mod en sikker død (foondu og heendu), altid kun stilles retrospektivt. I løbet af feltarbejdet stødte hun kun på to endnu levende, men dødeligt syge børn, der fik disse diagnoser. I alle andre tilfælde blev de først brugt i retrospektive fortællinger om sygdomsforløb, der ledte op til et barns død.

Disse forfattere gør opmærksom på den afgørende betydning af tidspunktet for en diagnose. En diagnose kan ikke forstås uafhængigt af, hvornår i et sygdomsforløb den gives (eller kan i hvert fald, som de kritiserer Scheper-Hughes for, misfortolkes gevaldigt, hvis tidspunktet ikke medregnes). Umiddelbart fatalistiske diagnoser er i praksis ofte bagudrettede og kan være af stor betydning som trøst for de overlevende, ikke mindst moderen.

Jeg vil tage denne indsigt med mig til Uganda og tilføje, at ansvar ikke kun spiller en central rolle i forbindelse med retrospektive fortolkninger, men også i forbindelse med prospektive diagnoser. Da Akoth bragte theri på tale, skete det på et vist tidspunkt $i$ et længere sygdomsforløb. Det var en fremadrettet fortolkning af datterens symptomer, og det var et svar på de nære slægtninges manglende ansvarlighed. Tilsvarende var Awori i gang med ikke kun at fortolke, hvad der var sket med de to børn, hun allerede havde mistet, men også med at skabe sig et liv, der ville gøre det muligt for hende at holde kommende børn i live. Hun fortolkede deres død i rammerne af juok og kastede denne fortolkning ind i fremtiden i håbet om at få sin svigerfamilies anerkendelse og støtte. Fortolkning af sygdom finder sted i tid, ikke $\mathrm{i}$ isolerede øjeblikke. Det er en fortolkning af noget allerede sket med fremtiden for øje.

\section{Fra betydning til praksis: Hvor hurtigt?}

Når vi taler om livet i tid, er det væsentligt at se på, hvordan sociale aktører gør strategisk brug af tid og af tempo (Bourdieu 1990:81). Det, vi gør, kan have meget forskellig betydning og få meget forskellige konsekvenser afhængigt af, hvornår vi gør det, og med hvilken hastighed vi gør det, dvs. hvilket tempo vores handlinger finder sted $\mathrm{i}$.

Jeg var længe om at forstå forskellen på koyo og musujja, og det skete ikke, før jeg gennem deltagelse i adskillige sygdomsepisoder forstod, at det handlede om forskel i tempi. Musujja leder ikke til hastige handlinger, men ofte blot til boden oppe ved vejen, der solgte cola, sæbe, salt, panodiler og klorokintabletter. Når 
koyo derimod kommer på tale, er der behov for at handle hurtigt. Juogi indebærer et helt andet tempo. Awori bruger juogi til at forbinde sine børns sygdom med familiebegivenheder, der fandt sted for længe siden og kunne have været glemt, men som nu takket være juogis narrative struktur (plot) bliver en del af hendes svar på svigerfamiliens manglende lyst til at tage ansvar for hende og hendes børn. Hun forventer ikke, at der skal handles i dag (som hvis der var tale om koyo), men hun forventer, at familien forholder sig til situationen. I sidste ende bliver ritualet måske aldrig udført, men under alle omstændigheder vil der være tale om et tidsinterval, som er noget andet end et tomt, uvirksomt tidsrum (jf. Bourdieu 1990:106). Ethvert forsøg på at manipulere tid - ved at ændre tempo (ved f.eks. at foretage en bestemt fortolkning af et barns symptomer), fremskynde eller bremse ting - rykker ved de strukturer, vi lever i, f.eks. vores sociale relationer (op.cit.: 81). Ved at sætte forholdet til svigerfaderen ind i juogis tempo forsøger Awori at ændre deres forhold. Svigerfaderen forsøger til gengæld at lade tiden arbejde for ham ved at undlade at gøre noget. Han udsætter de handlinger, hun forventer af ham, ved at sende hende tilbage til sundhedscenteret. Hun modsætter sig denne opbremsning ved at pointere, at der har hun allerede været adskillige gange.

Det var tydeligt i exitinterviewene, at også ,hospitalssygdomme“ indebærer et vist tempo. Når man præsenterer et sygdomsforløb for en sundhedsarbejder, gør man det med fokus på de symptomer, man har bemærket inden for de sidste få dage, og som man mener kræver behandling her og nu. I andre sociale sammenhænge sætter man måske disse symptomer ind i et længere sygdomsforløb og knytter dem sammen med begivenheder og handlinger, der ligger længere tilbage og/eller fremme i tiden. Men ofte giver dette ikke mening inden for rammerne af sundhedscenteret, og derfor bliver disse narrative strukturer ikke en del af patientens svar på sundhedsarbejdernes handlinger.

Opsummerende vil jeg altså foreslå, at en diagnose kan forstås som en narrativ struktur eller et plot, der påkalder sig sociale aktørers ansvar gennem forskellige måder at bringe fortiden, nutiden og fremtiden i fokus og ved brug af forskellige tempi til at binde begivenheder sammen eller skabe opmærksomhed omkring særlige begivenheder og handlinger. Diagnosernes narrative struktur kan gøre opmærksom på diarreen i sidste uge, der måske ellers ville være blevet ignoreret, mandens utroskab, manglen på mad, behovet for længere pauser mellem de mange børnefødsler m.m. De kommenterer ikke blot på, hvad der allerede er sket, men peger på, hvad der burde gøres, hvem der burde gøre det og hvor hurtigt. Mødrene bevæger sig frem og tilbage mellem symptomatisk behandling på sundhedscentre og diverse former for lokale diagnoser og behandlingsformer, fordi de bevæger sig i forskellige sociale rum og trækker på forskellige menneskers ansvar og derfor også må forholde sig til forskellige tidsligheder og tempi. 


\section{Konklusion: Narrativer, der handler om handling}

En sygdomsforklaring, eventuelt i form af et fortalt narrativ, skal ses som del af en større sammenhæng af levede narrativer. Fortalte narrativer om fortolkningen af et barns velvære er altid et aspekt af levede narrativer. Næste del af disse levede narrativer består måske $i$ at tage på sundhedscenteret, købe tabletter, spørge svigermor eller sandsigeren til råds eller gøre helt andre ting, som kan lede livet på rette vej.

Når en mor fortæller om sit barns tilstand, skal vi spørge, hvorfor hun netop nu er ved at lave netop denne fortolkning af fortiden, og hvordan hun er ved at kaste den ind i fremtiden, dvs. hvilke veje frem hun er ved at afsøge, og hvordan hun forsøger at få andre til at bevæge sig i en for hende fordelagtig retning. Mange fortalte narrativer, mange fortolkninger af det skete, vil blive afprøvet og kastet ind i fremtiden. Mange veje vil blive afprøvet. Det er ikke nødvendigvis ønskværdigt at kende slutningen på forhånd. Som mødrene på introduktionsmødet gjorde mig opmærksom på, var det ikke interessant at tale om aids, så længe denne histories slutning kun var alt for velkendt. ${ }^{6}$

Når jeg undredes over fravær af handling blandt mødrene i det østlige Uganda, skyldtes det ofte min manglende evne til at få øje på disse handlinger. Det var ikke nødvendigvis det, de sagde, og heller ikke altid deres åbenlyse handlinger, der var det mest sigende. Diagnoser blev ikke altid stillet i eksplicit tale, men implicit ved f.eks. at påpege symptomer og forandringer i barnet (alt fra knyttede hænder til diarré) eller i faderens eller bedsteforældrenes adfærd (utroskab, manglende ofringer til forfædre) eller i udøvelse af visse former for behandling, fravær af anden behandling, ved at tage visse foranstaltninger (sociale, religiøse osv.) og undlade andre. Deres handlinger bestod altså også i det, de ikke gjorde som led i et forsøg på at manipulere med tid - i fraværet af handlinger, i tavsheder, udsættelser eller fremskyndelser af handlinger. Og i det, de gjorde ved at sige ting i det stille som f.eks. ved fortolkning af deres børns symptomer.

Gennem ord og handlinger, men også fravær af ord og handlinger, manipuleredes med tid og det sociale rum: elementer, som er nogle helt andre i sundhedscenteret end hjemme på bostedet blandt familiens medlemmer. Derfor giver de diagnoser, der anvendes hjemme, ikke mening i sundhedscenteret. Derfor forventer folk ikke, at disse diagnoser kommer på tale i løbet af konsultationen. På sundhedscenteret handles der også, men på helt andre måder.

Det er slående, at ordet ,plot“" oversættes til „,handling“ på dansk. Måske skyldes dette netop, at en fortællings handling simpelt hen drejer sig om, hvordan og hvorfor vi som mennesker handler - og ikke blot hvordan vi fortolker vores erfaring og tillægger lidelse betydning. Sygdomsforklaringer og sygdomshåndtering, betydning og dens konsekvenser er to sider af samme sag. Hvis vi holder fast $\mathrm{i}$ 
dette, øger vi chancerne for at bidrage til en forståelse af sundhedssøgende uden at reproducere det biomedicinske paradigmes implicitte antagelser.

\section{Noter}

1. I 1995-96 udførte jeg mit ph.d.-feltarbejde i området, finansieret af Rådet for Ulandsforskning. Dette feltarbejde såvel som flere opfølgende feltarbejder har været del af forskningssamarbejdet TORCH (Tororo Community Health) mellem Institut for Antropologi, Københavns Universitet, og Child Health and Development Centre, Makere University, finansieret af Danida.

2. Jop'adhola er en af flere etniske grupper i den østlige del af Uganda, der taler distinkte sprog og definerer sig selv som ,stammer“. Andre er banyole, basamia og iteso. Det er svært at finde tal på, hvor mange der tilskriver sig de enkelte grupper, men der er sandsynligvis et par hundrede tusinde jop'adholaer.

3. Jop'adholaerne taler et nilotisk sprog og er nært beslægtet med andre af de såkaldt nilotiske folk, der har levet og vandret ned langs Nilen og nu er bosat i bl.a. det sydlige Sudan, nordlige Uganda, vestlige Kenya og for nogle enkelte folks vedkommende også i det østlige Uganda, der ellers hovedsageligt er beboet af folk, der taler bantusprog. De nilotiske sprog er indbyrdes beslægtet, men afviger markant fra bantusprog, der er den dominerende sprogstamme i Afrika syd for Sahara.

4. Studiet blev udført i forbindelse med det ovennævnte forskningssamarbejde, TORCH (se note 1). For en mere detaljeret præsentation af studiet og dets resultater, se Nshakira et al. (1996).

5. Et eksempel på brug af pragmatismen inden for medicinsk antropologi er Susan Whytes bog Questions of Misfortune. The Pragmatics of Uncertainty in Eastern Uganda (1997), hvor hun inspireret af pragmatikerne James og Dewey viser, hvordan folk, der søger at håndtere lidelse, først og fremmest er optaget af konsekvenser, og at intentioner og konsekvenser er to sider af samme sag.

6. Situationen er en anden nu 12 år senere, hvor livsforlængende aidsmedicin er blevet almindeligt forekommende i Uganda. Det kan stadig være problematisk at få børn testet og i gang med behandling, men alt $i$ alt er aids ved at ændre sig til en diagnose, der har fremtidsperspektiver.

\section{Litteratur}

Bourdieu, Pierre

1990 The Logic of Practice. Stanford: Stanford University Press.

Bruner, Edward M.

1986a Experience and its Expressions. I: V.W. Turner \& E.M. Bruner (eds.): The Anthropology of Experience. Urbana: University of Illinois Press.

1986b Ethnography as Narrative. I: V.W. Turner \& E.M. Bruner (eds.): The Anthropology of Experience. Urbana: University of Illinois Press.

Castle, Sarah E.

1994 The (Re)negotiation of Illness Diagnoses and Responsibility for Child Death in Rural Mali. Medical Anthropology Quarterly 8(3):314-35.

Douglas, Mary

1966 Purity and Danger. London: Routledge. 
Fabrega, Horacio

1970 On the Specificity of Folk Illnesses. Southwestern Journal of Anthropology 26: 304-14.

Foster, George M.

1976 Disease Etiologies in Non-Western Medical Systems. American Anthropologists 78:773-82.

Geertz, Clifford

1973 Thick Description: Toward an Interpretive Theory of Culture. I: C. Geertz: The Interpretation of Cultures. New York: Basic Books.

Gausset, Quentin \& Hanne. O. Mogensen

1996 Sida et pollutions sexuelles chez les Tonga de Zambie. Cahiers d'Etude Africaines 143(XXXVI-3):455-76.

Good, Byron

1977 The Heart of What's the Matter. The Semantica of Illness in Iran. Culture, Medicine and Psychiatry 1:25-58.

1994 Medicine, Rationality and Experience. An Anthropological Perspective. Cambridge: Cambridge University Press.

Hastrup, Kirsten

2005 Social Anthropology. Towards a Pragmatic Enlightenment? Social Anthropology 13(2):133-49.

2004 Action. Anthropology in the Company of Shakespeare. København: Museum Tusculanum Press.

Kleinman, Arthur

1973 Medicine's Symbolic Reality: On the Central Problem in the Philosophy of Medicine. Inquiry 16:206-13.

1980 Patients and Healers in the Context of Culture. An Exploration of the Borderland between Anthropology, Medicine, and Psychiatry. Berkeley: University of California Press.

1995 Writing at the Margin. Discourse between Anthropology and Medicine. Berkeley: University of California Press.

Kleinman, Arhur \& Joan Kleinman

1991 Suffering and its Professional Transformation. Toward an Ethnography of Interpersonal Experience. Culture, Medicine, and Psychiatry 15(3):275-301.

Mattingly, Cheryl

1994 The Concept of Therapeutic 'Emplotment'. Social Science \& Medicine 28(6):81122.

1998 Healing Dramas and Clinical Plots. The Narrative Structure of Experience. Cambridge: Cambridge University Press.

Mogensen, Hanne O.

1995 AIDS is a Kind of Kahungo that Kills: The Challenge of Using Local Narratives when Exploring AIDS among the Tonga of Southern Zambia. Oslo: Scandinavia University Press.

1996 Social respons på urbaniseringens epidemier: Aids-oplysning i det sydlige Zambia. Tidsskriftet Antropologi 34:17-27.

1997 The narrative of AIDS among the Tonga of Zambia. Social Science \& Medicine 44(4):431-9.

1999 Tro, viden og international sundhed. Bibliotek for Læger 191(2):183-5. 

and Psychiatry 24:331-51.

2002 The Resilience of Juok: Confronting Suffering in Eastern Uganda. Africa 72(3): 420-36.

Nations, Marilyn \& Linda-Anne Rebhun

1988 Angels with Wet Wings Won't Fly: Maternal Sentiment in Brazil and the Image of Neglect. Culture, Medicine and Psychiatry 12:141-200.

Nshakira, Nathan et al.

1996 Quality of Care in Out-Patient Health Facilities in Tororo District. Kampala: Child Health and Development Centre. Upubliceret rapport.

Paul, Benjamin David

1955 Introduction: Understanding the Community. I: B.D. Paul (ed.): Health, Culture and Community: Case Studies of Public Reactions to Health Programs. New York: Russell Sage Foundation.

Ricoeur, Paul

1991 Life in Quest of Narrative. I: D.C. Wood (ed.): On Paul Ricoeur. Narrative and Interpretation. London: Routledge.

Scheper-Hughes, Nancy

1985 Culture, Scarcity, and Maternal Thinking: Maternal Detachment and Infant Survival in a Brazilian Shantytown. Ethos 13(4):291-317.

1992 Death without Weeping: The Violence of Everyday Life in Brazil. Berkeley: University of California Press.

Whyte, Susan

1997 Questions of Misfortune. The Pragmatics of Uncertainty in Eastern Uganda. Cambridge: Cambridge University Press.

Yoder, Stanley

1997 Negotiating Relevance: Belief, Knowledge and Practice in International Health Projects. Medical Anthropology Quarterly 11(2):131-46. 
